\title{
Revitalizing Irrigation Systems for Reducing Effects of Climate Change on Irrigated Agriculture in Nepal
}

Mahesh Man Shrestha

\begin{abstract}
Effects of Climate Change (CC) on hydrology and irrigated agriculture in Nepalese irrigation systems will be one of the major constraints in near future in irrigation development. The current status of Nepalese irrigation systems is highlighted briefly with its problems, constraints, challenges and opportunities, and current public policies and regulations in irrigation are summarized briefly with their relevancy and constraints. Reviewing the Agricultural Perspectives Plan (APP) and other policy and strategy frameworks, analyzing its performance and the relevance of its priorities and strategies to the current situation, and based on above facts mitigation and adaptation measures are suggested for short, medium and long-term strategies to revitalize irrigation systems of Nepal for irrigated agriculture enhancement. Suggestions and recommendations to incorporate are made in formulating its principle strategy into a forthcoming Irrigation Policy framework.
\end{abstract}

Key words: Irrigated agriculture, revitalizing irrigation systems, climate change mitigation measures, Nepal

\section{Introduction} A griculture forms the backbone of the Nepalese to the gross domestic production (GDP). Over $70 \%$ of the population directly or indirectly depends on agriculture, and $70 \%$ of them are subsistence farmers (NCVST 2009). Presently, the population involved in agriculture is estimated to be employed for half of the year only, due to unavailability of irrigation throughout the year. Reduction of poverty is possible if efforts are made towards providing full employment to the people depending on agriculture by providing year round irrigation in the irrigable areas. Water and its availability and quality will be the main pressures on, and issues for, societies and the environment under climate change (IPCC 2007).

\section{Effects of Climate Change on Hydrology and Irrigated Agriculture}

Glaciers in the Nepal Himalayas are shrinking rapidly and if the current glacier melting rate continues there will be no glaciers left by 2180 . Most of the small glaciers will disappear within 3-4 decades (Chaulagain 2006). There will be only $11 \%$ of the present glacier-ice left by $\mathrm{AD} 2100$; even if the present temperatures do not rise (Chaulagain 2006).
In fact, global warming is accelerating the melting of Himalayas glacier at a rate faster than the global average (Sharma, Chettri et al 2009). Accelerated glacier melt increases water availability at the beginning, but reduces it after the glaciers disappear. There will be a problem of floods and landslides during the rainy seasons whereas the problem of droughts during the dry seasons. Decline in snowfall in the winter is likely to reduce the availability of pastures in the area during summer. The decrease in grazing livestock will lead to the reduction of manure supply for the farms. This in turn will inhibit the recovery of both the crop and the pastures which ultimately is likely to hamper the regenerative capacity of the production system. Livestock also forms a crucial part of the trekking industry as animal used for transportation and is a source of income for many households in mountainous area. Late snowfall (during spring) may result in the emergence of some pests and diseases that affect agricultural plants and their harvesting.

Most of the sources of small and medium surface irrigation systems are originated from Chure and Mahabharat hills with a low to almost zero flow during the dry season. Due to lack of proper water management in Agency Managed Irrigation Systems (AMIS) only 30 to $40 \%$ of the command area is irrigated during winter season.

\begin{tabular}{|c|c|c|c|c|c|c|c|c|}
\hline \multirow{3}{*}{ Planning Periods } & \multicolumn{5}{|c|}{ Through the DOI's Intervention } & \multirow{4}{*}{$\begin{array}{c}\text { FMIS } \\
\text { Traditional }\end{array}$} & \multirow{3}{*}{$\begin{array}{l}\text { Total } \\
\text { Irrigated } \\
\text { Areas }\end{array}$} & \multirow{3}{*}{$\begin{array}{c}\text { Total } \\
\text { Irrigated } \\
\text { areas at the } \\
\text { End of the } \\
\text { Plan Period }\end{array}$} \\
\hline & \multicolumn{3}{|c|}{ Surface irrigation systems } & \multirow{2}{*}{$\begin{array}{l}\text { Through } \\
\text { GW } \\
\text { Irrigation } \\
\text { System } \\
\end{array}$} & \multirow[b]{2}{*}{ Total } & & & \\
\hline & $\begin{array}{c}\text { New } \\
\text { Irrigation }\end{array}$ & $\begin{array}{c}\text { FMIS } \\
\text { Improvement }\end{array}$ & Total & & & & & \\
\hline Before 1st Five Year Plan & & & 6,228 & & 6,228 & & 6,228 & 6,228 \\
\hline $\begin{array}{l}\text { From 1st Five year to } 7 \text { th } \\
\text { Five Year Plan and at the } \\
\text { end of Interim Plan }\end{array}$ & & & 352,076 & 109,098 & 461,174 & 381,814 & 842,988 & 849,216 \\
\hline 8th Five Year Plan & & & 146,178 & 60,223 & $2,06,401$ & & 206,401 & $1,055,617$ \\
\hline 9th Five Year Plan & 29,586 & 80,879 & 110,465 & 36,238 & 146,703 & 300,935 & 65,824 & $1,121,441$ \\
\hline 10th Five Year Plan & 25,504 & 14,298 & 39,802 & 47,683 & 87,485 & 286,637 & 73,187 & $1,194,628$ \\
\hline 3 year Interim Plan & 11,394 & 12,434 & 23,828 & 46,454 & 70,282 & 274,203 & 57,848 & $1,252,476$ \\
\hline
\end{tabular}

Table 1. Irrigated Area Developed During the Different Plan Periods (Area in Hectares) (Project Design, Monitoring and Evaluation Division, Department of Irrigation, Jawalakhel, Lalitpur). 
The hydropower potential of country will also be reduced due to reduced water availability in the Himalayas.

\section{Current Status of Irrigation Development in Nepal with its Problems, Constraints, Challenges and Opportunities \\ Status of irrigation development}

Irrigation infrastructures development covers about 1.252 million hectares ( $\mathrm{m} \mathrm{ha}$ ) out of $2.65 \mathrm{mha}$ of cultivated land and $1.76 \mathrm{mha}$ of irrigable land. The developed infrastructure covers around $71 \%$ of potential irrigable area of the country.

Table 1 gives an idea of irrigation development in the country. About $41 \%$ of net irrigated area is being supplied with year round irrigation. It is estimated that existing irrigation systems are the basis for approximately $65 \%$ of the current agricultural production of the country (WECS 2003). A large volume of water is available in the shallow and deep aquifers which are estimated to be 8.8 billion cubic meter (bcm) annually (Pokharel and Shakya 2011).

The irrigation development program in the country is not satisfactory in terms of the set objectives, for the following reasons:

\section{Problems and constraints in irrigation development}

- Non availability of water during lean period in the source of existing irrigation systems.

- Resource constraint to develop irrigation systems through intra- basin transfer for year round irrigation.

- Unsatisfactory people's participation in sharing operation and maintenance (O\&M) and capital cost of system.

- Insufficient budget allocation for O\&M.

- Low water use efficiencies.

- High operating cost of tube well due to price hike of fuels.

- Non-availability of electricity due to limited generation capacity.

- Weak institutional capability of agencies.

- Weak linkages between agriculture and irrigation.

\section{Challenges and opportunities}

- Agency Managed Irrigation Systems (AMIS) have increased crop yields by two folds with over $60 \%$ increase in cropping intensity showing the positive impact (see Table 2).

- Irrigation systems developed during 1970 s needs maintenance of their infrastructures. A rehabilitation program of Farmer Managed Irrigation Systems (FMISs) should be designed in such a way that it could enhance their traditional system keeping their management system intact without any interruption.

- Year Round (YR) irrigation is not possible unless basin transfer systems or storage reservoirs are developed. Storage reservoir should be carefully planned to avoid the submergence of valuable productive lands of the country. This necessitates the big engineering intervention requiring huge investment as well as technical competency to cope with the demand.

- The Irrigation Service Fee (ISF) paid by the farmers is less than $3 \%$ of the required O\&M costs.

- Support services like promotion of agricultural market, improvement of farm roads, provision of agricultural inputs and rural electrification is lacking for commercialization of the crops.

- Necessary to develop and implement the appropriate technology to address the people in isolated marginal lands by adopting nonconventional irrigation systems.

- Subsistence farming, and skewed land distribution with very small land holdings are also constraints for irrigation development.

- Effective transformation of policy to the field level and monitoring of the programs is lacking.

\section{Public Policies and Regulations in Irrigation Sector National Water Resource Strategy 2002 (NWRS)}

NWRS provides clear vision for irrigation development and has adapted the following strategies:

- Integrate irrigation planning and management with agricultural development.

- Improve water management of existing irrigation systems.

- Develop year round irrigation in support of intensification and diversification of agriculture.

- Strengthen local capacity for management of irrigation systems.

- Encourage consolidation of land to promote irrigation/agriculture efficiency.

- Improve ground water (GW) development and management.

Nepal has adopted integrated water resources management (IWRM) principles in the development and management of water sector and the effort is geared towards social and economic development and environmental sustainability. Moreover, IWRM is only partially practiced.

\section{Irrigation Policy (IP) 2003}

Following are the objectives set out by IP-2003:

- Provide year round irrigation service to the irrigable land by effective utilization of the water resources.

- Develop institutional capability of WUAs for the sustainable management of existing system.

- Enhance the knowledge, skill and institutional working capability of irrigation professionals, WUAs and NGO relating to irrigation development sector.

High priority has been given to implement the diversion projects which can provide year round irrigation to significant area. On small marginal lands situated in isolation in the hills and mountains and on degraded land in the lowland terai plain, non-conventional irrigation 


\begin{tabular}{|c|c|c|c|c|c|c|c|c|}
\hline \multirow[b]{2}{*}{ Name of Project } & \multicolumn{4}{|c|}{ Crop Yields (mt/ha) } & \multicolumn{2}{|c|}{ Yields } & \multicolumn{2}{|c|}{ Cropping Intensity } \\
\hline & $\begin{array}{l}\text { Early } \\
\text { Main }\end{array}$ & $\begin{array}{l}\text { Paddy } \\
\text { Paddy }\end{array}$ & Wheat & Maize & $\begin{array}{l}\text { Average } \\
\text { (t/ha) }\end{array}$ & $\begin{array}{l}\text { Increment } \\
\text { in } \%\end{array}$ & $\begin{array}{c}\text { Average } \\
\%\end{array}$ & $\begin{array}{l}\text { Increment } \\
\text { in } \%\end{array}$ \\
\hline Irrigation Line of Credit (ILC) ${ }^{1}$ & $\begin{array}{r}(2.51) \\
3.01\end{array}$ & $\begin{array}{r}(1.93) \\
2.71\end{array}$ & & & $\begin{array}{r}(2.22) \\
2.86\end{array}$ & 29 & $\begin{array}{r}(149) \\
178\end{array}$ & 29 \\
\hline Sunsari-Morang Phase-I ${ }^{2}$ & $\begin{array}{r}(2.80) \\
3.50\end{array}$ & $\begin{array}{r}(2.90) \\
3.40\end{array}$ & $\begin{array}{r}(2.1) \\
2.70\end{array}$ & $\begin{array}{r}(2.00) \\
3.00\end{array}$ & $\begin{array}{r}(2.45) \\
3.15\end{array}$ & 29 & $\begin{array}{r}(152) \\
178\end{array}$ & 26 \\
\hline $\begin{array}{l}\text { Sunsari-Morang } \\
\text { Phase-II }{ }^{3}\end{array}$ & $\begin{array}{r}(1.6) \\
3.5\end{array}$ & $\begin{array}{r}(2.4) \\
3.4\end{array}$ & $\begin{array}{r}(1.40) \\
2.7\end{array}$ & $\begin{array}{r}(1.60) \\
3.00\end{array}$ & $\begin{array}{r}(1.75) \\
3.15\end{array}$ & 80 & $\begin{array}{r}(129) \\
178\end{array}$ & 49 \\
\hline $\begin{array}{l}\text { East Rapti Irrigation Project, } \\
\text { Chitwan }{ }^{4}\end{array}$ & $\begin{array}{r}(3.50) \\
3.75\end{array}$ & $\begin{array}{r}(3.18) \\
3.95\end{array}$ & $\begin{array}{r}(2.36) \\
2.87\end{array}$ & $\begin{array}{r}(1.88) \\
2.09\end{array}$ & $\begin{array}{r}(2.73) \\
3.17\end{array}$ & 16 & $\begin{array}{r}(164) \\
229\end{array}$ & 65 \\
\hline $\begin{array}{l}\text { Kankai Irrigation Project, } \\
\text { Jhapa }^{5}\end{array}$ & $\begin{array}{r}(0.00) \\
4.50\end{array}$ & $\begin{array}{r}(0.00) \\
3.20\end{array}$ & $\begin{array}{r}(0.00) \\
1.5\end{array}$ & $\begin{array}{r}(0.00) \\
1.6\end{array}$ & $\begin{array}{r}(0.00) \\
2.70\end{array}$ & & $\begin{array}{r}(145) \\
190\end{array}$ & 45 \\
\hline $\begin{array}{l}\text { Rajapur Irrigation Project, } \\
\text { Bardiya } 6\end{array}$ & $\begin{array}{r}(0.00) \\
3.40\end{array}$ & $(2.49)$ & $\begin{array}{r}(1.70) \\
214\end{array}$ & $\begin{array}{r}(0.85) \\
1.18\end{array}$ & $\begin{array}{r}(1.68) \\
2.22\end{array}$ & 32 & $\begin{array}{r}(186) \\
191\end{array}$ & 5 \\
\hline $\begin{array}{l}\text { Marchwar Irrigation Project, } \\
\text { Rupendehi }{ }^{7}\end{array}$ & $\begin{array}{r}(0.00) \\
3.20\end{array}$ & $(1.52)$ & $\begin{array}{r}(1.46) \\
2.20\end{array}$ & $\begin{array}{r}(0.00) \\
0.00\end{array}$ & $\begin{array}{r}(1.49) \\
2.70\end{array}$ & 81 & $\begin{array}{r}(135) \\
186\end{array}$ & 51 \\
\hline Bhairahawa-Lubini GW Project ${ }^{8}$ & $\begin{array}{r}(0.00) \\
2.50\end{array}$ & $\begin{array}{r}(1.70) \\
3.90\end{array}$ & $\begin{array}{r}(1.00) \\
2.79\end{array}$ & $\begin{array}{r}(0.00) \\
2.61\end{array}$ & $\begin{array}{r}(1.35) \\
2.95\end{array}$ & 119 & $\begin{array}{r}(120) \\
186\end{array}$ & 66 \\
\hline $\begin{array}{l}\text { Narayani Irrigation Project-I, } \\
\text { Persa }{ }^{9}\end{array}$ & $\begin{array}{r}(0.00) \\
0.00\end{array}$ & $\begin{array}{r}(2.10) \\
3.20\end{array}$ & $\begin{array}{r}(1.20) \\
2.60\end{array}$ & $\begin{array}{r}(0.00) \\
2.00\end{array}$ & $\begin{array}{r}(1.10) \\
2.60\end{array}$ & $\begin{array}{r}(0.00) \\
136\end{array}$ & $\begin{array}{r}(141) \\
188\end{array}$ & 47 \\
\hline Second Hill Irrigation Project ${ }^{10}$ & $\begin{array}{r}(0.00) \\
2.60\end{array}$ & $(1.50)$ & $\begin{array}{r}(1.00) \\
1.60\end{array}$ & $\begin{array}{r}(1.00) \\
1.80\end{array}$ & $\begin{array}{r}(1.16) \\
2.00\end{array}$ & 72 & & \\
\hline \multirow[t]{2}{*}{$\begin{array}{l}\text { Mahakali Irrigation Project } \\
\text { I\& II }{ }^{11}\end{array}$} & $\begin{array}{r}(0.00) \\
3.65\end{array}$ & $(1.98)$ & $\begin{array}{r}(1.57) \\
2.12\end{array}$ & $\begin{array}{r}(1.31) \\
2.32\end{array}$ & $\begin{array}{r}(1.62) \\
2.70\end{array}$ & 66 & $\begin{array}{r}(170) \\
195\end{array}$ & 25 \\
\hline & Paddy & Wheat & Linseed & Pulses & Mustard & $\begin{array}{c}\text { Increment } \\
\%\end{array}$ & Average & \\
\hline \multirow[t]{2}{*}{$\begin{array}{l}\text { Chandra Canal Irrigation } \\
\text { Project }\end{array}$} & $\begin{array}{r}(1,23) \\
2.30\end{array}$ & $\begin{array}{r}(0.00) \\
1.93\end{array}$ & $\begin{array}{r}(0.46) \\
0.56\end{array}$ & $\begin{array}{r}(0.76) \\
0.76\end{array}$ & $\begin{array}{r}(0.46) \\
0.60\end{array}$ & 112 & $\begin{array}{r}(0.65) \\
1.23\end{array}$ & \\
\hline & Paddy & Wheat & Lentil & Millet & Mustard & $\begin{array}{r}\text { Increment } \\
\%\end{array}$ & Average & \\
\hline Chourjaharitar Irrigation Project & $\begin{array}{r}(2.00) \\
3.00\end{array}$ & $\begin{array}{r}(1.40) \\
2.00\end{array}$ & $\begin{array}{r}(1.00) \\
1.50\end{array}$ & $\begin{array}{r}(1.00) \\
2.00\end{array}$ & $\begin{array}{r}(0.30) \\
0.40\end{array}$ & 56 & $\begin{array}{r}(1.14) \\
1.78\end{array}$ & \\
\hline $\begin{array}{ll}\text { Notes: } \\
1 & \text { System Performance and E } \\
2 & \text { Project Completion Report } \\
3 & \text { Project Completion Report } \\
4 & \text { Project Performance Audit } \\
5 & \text { Sustainable Irrigation Turno } \\
6 & \text { Draft Project Completion Re } \\
7 & \text { Final Evaluation (UNCDF/Un } \\
8 & \text { Project Completion Report } \\
9 & \text { Project Completion Report ( } \\
10 & \text { Feasibility Study Report of } \\
11 & \text { Feasibility Study Report of }\end{array}$ & $\begin{array}{l}\text { luation Rep } \\
\text { Stage-II (I } \\
\text { Stage-II ( } \\
\text { port (ADB } \\
\text { er Study (D } \\
\text { ort (ADB 2 } \\
\text { P 2002) } \\
\text { ahal Consu } \\
\text { rrld Bank 1 } \\
\text { ahakali-III } \\
\text { ahakali-III }\end{array}$ & $\begin{array}{l}\text { Dort (Halcrc } \\
\text { World Bank } \\
\text { World Bank } \\
\text { 2002) } \\
\text { FID/ Walli } \\
\text { 003) } \\
\text { Itants 199 } \\
982) \\
(2001) \\
(2001)\end{array}$ & $\begin{array}{l}\text { W/GEOCE/E } \\
1996) \\
1996) \\
\text { ggford } 2001\end{array}$ & East 1997) & & & & \\
\hline
\end{tabular}

Table 2. Crop Production and Cropping Intensity in Different AMISs (Numbers in brackets show condition before project) (Source: www.ndf2004.gov.np/ pdf/proceedings/irrigation.pdf.). 
programs have been initiated. Landholding size has been considered in project selection, implementation and costsharing criteria.

The objectives of the proposed forthcoming draft of IP are as follows:

- GON (Government of Nepal) shall declare the area with irrigation service as irrigated area. Provision shall be made to use land within irrigated area for non agricultural purpose for which necessary permission has to be obtained in advance.

- To provide reliable irrigation services for year round irrigation, a master plan shall be developed for transfer of water from big river to water deficit areas.

- Complementary use approach for the utilization of surface and ground water resources for irrigation will be adopted. In case of ground water necessary preservation, maintenance and water quality control shall be done.

- Institutional development and skill enhancement, to implement multi-purpose reservoir or inter basin transfer projects will be conducted by providing training and research skills. A central level human skill development and research unit will be established. Policy will be adopted to involve private sector in irrigation development.

- Adaptation program to mitigate the adverse effect of global climate change will be designed and implemented.

\section{Review of the APP Strategy and Other Policies in Irrigation}

The APP (1995) proposed to irrigate 612,000 ha of the terai lowland by groundwater by the year $2015 \mathrm{AD}$, mainly through Shallow Tube Wells (STWs). This basic design concept of APP seems to be questionable and revisiting it in the present context is suggested, for these reasons:

- STWs are generally used for high value crops which are grown not more than $10 \%$ to $15 \%$ of the total cultivated area.

- Farmers grow mainly cereal crops and all these crops are irrigated by surface irrigation. STWs are not used for irrigating such cereal crops because it is not viable economically.

- STWs are used for growing the seedlings of paddy in some areas when there is no rainfall. It seems that planners have ignored the fact that farmers will not run tube well in cereal crops.

- The lives of STWs are eight to 10 years and have to be replaced after such periods.

- Diesel operated systems are costly and electricity is not available for these purposes. The country has insufficient electricity and there is no hope for improvement of the situation in the near future.

- STWs run not more than 200 to 400 hours/year presently. In order to make them viable they should run not less than 1,00o hours/year.

- O\&M of STWs are comparatively complicated. The entire pump sets, fuels and spare parts are imported.
- During APP formulation stage a provision for subsidizing the installation of STWs was included, but it was removed during the implementation period, which adversely affected the progress of installing STWs.

- Due to the open border, Nepalese farmers cannot compete in the produce markets due to comparatively high cost of production.

- The IP-2003 is more holistic, progressive and inclusive than the APP while dealing with irrigation, but it does not adequately deal with the groundwater issues. This necessitates updating APP policy and strategies to make them consistent with the IP-2003.

\section{Mitigation and Adaptations Measures to Revitalizing Irrigation Systems in Terai, Hills and Mountains of Nepal}

Communities, government and NGO stakeholders at local level are not aware of global climate change. Climate change adaptation requires an integrated approach including socio-economic development, environmental conservation and disaster risk reduction. Different types of materials and approaches such as slides, films, field observations, road drama, dohari songs, leaflets, pamphlets, etc should be used to make the target population aware on climate change. A watershed level committee should be formed represented by all the settlement within the watershed including the WUAs. This committee will be involved in all the stages of activities of climate change such as identifying the issues and activities, its planning and implementation.

Adoption steps to be taken for Terai are as follows:

- Adaptation to water shortages need to be investigated considering a holistic and integrated development approach for water resources development and management, promotion of indigenous technologies.

- Basin transfer from water rich River sources to water deficit area need to be given priority for running already built irrigation systems in full capacity throughout the year.

- Due to availability of the sufficient water farmers may have a tendency to use over irrigation. This requires further strengthening of the protection works and the drainage systems.

- Increase water use efficiencies of the project through good water management practice and implementation of irrigation management transfer (IMT) system. Net effects of more effective irrigation on the Green House Gas (GHG) budget need to be better understood (higher carbon storage in soils through enhanced yields and residue returns and its offset by carbon dioxide (CO2) emissions from energy systems to deliver water or by nitrogen oxide (N2O) emissions from higher moisture and fertilizer inputs).

- Land consolidation is emphasized by the IP-2003, but there is no sign of its implementation. We must initiate land consolidation program in irrigated areas by initiating pilot projects and preparing 
necessary acts and regulations with the socioeconomic supports.

- In the absence of reliable projections of climate change information we could initiate the program such as improved water management activities to cope with climate change.

- Monitoring of GW table, ground water quality and maintaining its draw down to a permissible limit should be done regularly.

- Use of the treadle pumps, sprinkler, drip systems for cultivating high value crops such as vegetable, fruits etc in the farmers of marginal lands.

- Rehabilitation of AMIS and FMIS should be given priority to continue their agriculture activities and diversify the crops for both home consumptions and income generation.

- Activities like hazard mapping, river channelization and flood plain management, landslide protection works, awareness raising and capacity building of involved institutions and affected people in emergency flood fighting, etc., are to be implemented.

- Varietal changes and low water consuming technologies are to be given prime consideration. With the increase of temperature higher temperature adopting varieties are to be adopted.

- Research and innovation carried out by other countries also studied and adopted.

- Agriculture should take the lead role not the irrigation- it is just an input.

- Adaptation steps to be taken for hills and mountains systems are as follows:

- Small tank systems with appropriate lining should be built for water harvesting systems. More emphasis should be given to drip, sprinkler with piping systems for irrigation.

- Crop diversification with suitable high value crops should be encouraged. Diversify crop species and varieties that can best suited under erratic rainfall and water condition. Capacity building for more water-efficient cropping practices in local communities should be promoted.

- Traditional existing farmer's canals as well as new irrigation systems should be provided with sufficient escape facilities and necessary protection measures.

- IMT system should be implemented in large hill irrigation systems. Farmers and WUAs should be trained in improved soil and water management practices.

- Slope Land Agriculture Technique (SLAT) should be promoted to conserve soil and moisture. Farmers practice cultivation on slope lands without any terracing. Under such practice, it gets eroded when there is intensive rainfall. In order to help conserve the soil, SALT should be promoted. This technique included multipurpose plant species which helps increasing fodder production for livestock and income for the households in addition to help in stopping the soil erosion.

- High value crops and forestry should be given priority as suggested by APP.

\section{Suggested Measures to Rectify the Current Problems and Issues}

- Re-visit and update APP based on the actual situation and facts.

- Revise IP in the context of NWRS and Irrigation Master Plan 1990. Empower WUAs legally to manage irrigation systems and to collect ISF. Initiate involvement of private sector and NGOs in the development of irrigation, especially on ground water and other micro irrigation development.

- Water and Energy Commission Secretariat (WECS) should be given the mandate as written in the NWP for water policy. WECS should serve as a central disseminator of strategic climate change adaptation policy to all the ministries, who would then incorporate such policies into their development plans for the NPC and filter them down to the district and village level department offices.

- Real and pragmatic coordination mechanism between agriculture and irrigation is to be established in the grass root level.

- Prepare action plan to enhance the participatory approach to maximize the use of surface and ground water irrigation and to enhance the capacity of WUAs to take over the management transfer of those projects. Initiate user-focused design of irrigation systems for their sustainability.

- Nepal should use its natural slope and the surface water from perennial rivers which should be diverted through inter basin transfer to irrigate more new areas and to revitalize our already constructed irrigation systems instead of using only STWs. However, large trans-basin and storage projects in our present stage of socio-politico-economic situation are somewhat a remote possibility for materialization. Therefore small, medium surface irrigation together with groundwater option needs to be promoted as an interim measure.

- Basin transfer will recharge entire Terai ecosystems positively including the forest and its products with recharging the Terai ground water which could reduce the negative effects of climate change considerably.

- Strengthen drainage and protection of canal structures in all irrigation systems and especially in revitalized irrigation projects where water is available perennially.

- Collection of ISF should be based on irrigation service provided on crop and its area basis. It should not be as a compulsory tax basis without considering the irrigated area. Therefore the current draft of IP should be modified accordingly.

- Prepare action plan to enhance the participatory approach to maximize the use of surface and ground water irrigation and to enhance the capacity 
of WUAs to take over the management transfer of those projects. Initiate user-focused design of irrigation systems for their sustainability.

- Support services like promotion of agricultural market, improvement of farm roads, provision of agricultural inputs and rural electrification should be provided in ground water schemes for commercialization of the crops.

- Encourage women to participate in climate change activities in promoting the use of water resources, based on technical knowledge, cultural and ethical values to improve and manage our future limited freshwater resources.

- Rectify the institutional setups established for irrigation development to cater with existing sociopolitical and administrative mechanism. Real and pragmatic coordination mechanism between agriculture and irrigation is to be established in the grass root level.

Mahesh Man Shrestha, MS in Engineering from, USA, Irrigation Specialist. Mr. Shrestha has been involved in irrigation development work gaining wide experiences in ground water and surface irrigation both of farmers' and agency managed system. He has worked at different capacities (Secretary, Joint Secretary, Deputy Director General of IMD, Chief of FIWUD, Water Utilization Officer and Assistant Engineer) in various irrigation project implementation, studies including research, $M \& E$ and capability development of WUA's during his tenure (1968 to date).

Corresponding address: shresthamahesho8@gmail.com

\section{References}

APP, 2006, Implementation Action Plan Preparation, APP (Agricultural Perspective Plan), Implementation Status Report, Annexes, Kathmandu: National Planning Commission (High Level Task Force), with In Development Group Ltd. (UK) in association with NARMA Consultancy/Nepal and Seeport Consultancy/ Nepal.

Bartlett, R., L. Bharati, D. Pant, H. Hosterman and P. McCornick, 2010, Climate Change Impacts and Adaptation in Nepal, Colombo, Sri Lanka: International Water Management Institute.

Chaulagain, N.P., 2006, Impacts of Climate Change on Water Resources of Nepal: The Physical and Socioeconomic Dimensions, Dissertation for the Degree of Doctor Engineer, University of Flensburg, International Institute for Management, Energy and Environment, Flensburg, Germany.

DOI, 2011, Irrigation Policy 2011 (unpublished draft), Kathmandu: Department of Irrigation, Ministry of Irrigation.

DOI, 2010, Sichai Barsik Pustika 2066/2067 (Annual Irrigation Bulletin 2010/2011 AD), Kathmandu: Department of Irrigation, Ministry of Irrigation.
MWR/NPD, 2002, Medium Term Expenditure Framework (2002/3-2004/5), Irrigation Sector, Nepal Development Forum-2002, Kathmandu: Ministry of Water Resources/National Planning Commission.

GON/FAO/WFP/IFAD/ADB/WB, Nepal Initiating on Soaring Food Prices, Interagency Rapid Assessment Mission, 21-31 July, 2008, Draft Report of Mission Findings and Recommendations, Kathmandu: Government of Nepal.

IDL, 2006, APP (Agriculture Prospective Plan) Implementation Status Report, Volume I: Main Report, Final Report, Kathmandu: IDL Group Ltd., in collaboration with Norma Consultancy Pvt. Ltd. and Seeport Consultancy Pvt. Ltd.

IPCC, 2007, Climate Change 2007: Climate Change Inpacts, Adaptation and Vulnerability, Summary for Policy Makers, A report of Working Group II of the Intergovernmental Panel on Climate Change, Fourth Assessment Report, Cambridge University Press: UK.

Koirala, S.P., 2008, Water Resources Development (draft working paper for the donor consultation meeting), Kathmandu: Ministry of Water Resources.

MOE, 2007, Identifying Priorities and Opportunities for Actions on Climate Change Adaptation in Nepal, Workshop Proceeding, Kathmandu, 17 January, jointly organized by MOE, S\&T, DHM and Winrock International, Kathmandu: Ministry of Environment.

NCVST, 2009, Vulnerability Through the Eyes of the Vulnerable: Climate Change Induced Uncertainties and Nepal's Development Predicaments, Institute for Social and Environmental Transition (ISET), Nepal, Kathmandu: Nepal Climate Vulnerability Study.

Pant, D. and S. Madar, 2010, Synthesis of IWMI Work in Nepal, IWMI Working Paper 138, Colombo, Sri Lanka: International Water Management Institute.

Pokharel, A.P. and N.M. Shakya, 2011, Water Resources of Nepal in the Context of Climate Change, Kathmandu: Water and Energy Commission Secretariat.

Sharma E., N. Chettri, K. Tsering, A.B. Shrestha, F. Jing, P. Mool and M. Erikson, 2009, Climate Change Impacts in the Eastern Himalayas, Kathmandu: International Centre for Integrated Mountain Development.

Water Aid Nepal, 2005, Water Laws in Nepal, Laws Relating to Drinking Water, Sanitation, Irrigation, Hydropower and Water Pollution, Kathmandu: Water Aid Nepal.

WECS, 2003, Water Resource Strategy Nepal, Kathmandu: Water and Energy Commission Secretariat Kathmandu, Nepal.

World Bank, 2009, Shared Views on Development and Climate Change; URL: http://web. worldbank.org/Website/External/Countries/ Southasiaext/o,,contentMDK:22038355 pagePK:14 79 piPK:146830 theSitePK:223547,0o.html. 